

\title{
Evaluation of the antimutagenic activity and mode of action of carrageenan fiber in cultured meristematic cells of Allium cepa
}

\author{
C.I. Nantes ${ }^{1,2}$, J.R. Pesarini' ${ }^{2,3}$, M.O. Mauro ${ }^{2,4}$, A.C.D. Monreal', \\ A.D. Ramires ${ }^{2,3}$ and R.J. Oliveira $\mathbf{R}^{2,3,5}$ \\ ${ }^{1}$ Centro de Ciências Biológicas e da Saúde, \\ Universidade Federal de Mato Grosso do Sul, Campo Grande, MS, Brasil \\ ${ }^{2}$ Centro de Estudos em Célula Tronco, Terapia Celular e Genética Toxicológica, \\ Núcleo de Hospital Universitário, Universidade Federal de Mato Grosso do Sul, \\ Campo Grande, MS, Brasil \\ ${ }^{3}$ Programa de Pós-Graduação em Saúde e Desenvolvimento na Região \\ Centro-Oeste, Faculdade de Medicina, \\ Universidade Federal de Mato Grosso do Sul, Campo Grande, MS, Brasil \\ ${ }^{4}$ Programa de Doutorado em Biotecnologia e Biodiversidade - \\ Rede Pró-Centro-Oeste, Universidade Federal de Mato Grosso do Sul, \\ Campo Grande, MS, Brasil \\ ${ }^{5}$ Programa de Mestrado em Farmácia, Centro de Ciências Biológicas e da Saúde, \\ Universidade Federal de Mato Grosso do Sul, Campo Grande, MS, Brasil \\ Corresponding author: R.J. Oliveira \\ E-mail: rodrigo.oliveira@ufms.br
}

Genet. Mol. Res. 13 (4): 9523-9532 (2014)

Received February 18, 2014

Accepted August 8, 2014

Published November 12, 2014

DOI http://dx.doi.org/10.4238/2014.November.12.1

ABSTRACT. In this study, we evaluated the mutagenic and
antimutagenic activities of carrageenan, a sulfated polysaccharide, and
described its mode of action by using an Allium cepa assay. The results
indicate that carrageenan is not mutagenic, rather it has significant
chemopreventive potential that is mediated by both demutagenic and 
bio-antimutagenic activities. This compound can adsorb agents that are toxic to DNA and inactivate them. Additionally, carrageenan can modulate enzymes of the DNA repair system. The percentage of damage reduction ranged from 62.54 to $96.66 \%$, reflecting the compound's high efficiency in preventing the type of mutagenic damage that may be associated with tumor development. Based on these findings and information available in the literature, we conclude that carrageenan is an important fiber that should be considered as a possible base for functional foods and/or diets with potential anticancer activity.

Key words: Chromosome aberration; Micronucleus; Chemoprevention; Methyl methanesulfonate; Functional food

\section{INTRODUCTION}

Human beings are constantly exposed to potentially mutagenic substances that are characterized by their ability to chemically interact with DNA and cause genetic damage. Therefore, there is growing concern about increasing human exposure to chemical agents resulting from human activity because DNA damage can promote the development of both chronic and degenerative diseases (Antunes and Araújo, 2000; De Flora and Ferguson, 2005).

Such diseases, particularly cancers, are initiated by DNA damage events that were not effectively repaired by the cellular enzymatic DNA repair system. Inefficient repair of DNA damage results in mutations. If such damage is poorly repaired in germ cells, the individual's offspring become susceptible to genetic diseases, whereas if repair errors occur in somatic cells, the damage might result in cancer (Obe et al., 2002). Therefore, there is a growing need to develop preventive strategies involving substances with potential chemoprotective effects on genetic material (De Flora and Ferguson, 2005).

Among the possible sources of chemopreventive agents, complex polysaccharides are considered especially promising because a series of studies showed them to be biologically active compounds (Saksena et al., 1999) with many health-promoting effects, including antithrombotic, anticoagulant, antimicrobial, antiviral (Mišurcová et al., 2012), and antimutagenic/anticarcinogenic (Zong et al., 2012) activities.

Carrageenan is a high molecular weight, sulfated polysaccharide that is formed by alternating units of D-galactose and 3,6-anhydro-galactose linked by $\alpha(1-3)$ and $\beta(1-4)$ glycosidic bonds (Yuan and Song, 2005). These polysaccharides, which are found on the cell walls and intercellular matrix of tissues from algae in the phylum Rhodophyta, are divided into the following 6 basic forms according to the degree of sulfation: iota, kappa, lambda, mu, nu, and theta. The proportion of these different types varies according to the algal species, habitat, and time of collection (Khotimchenko, 2010).

Because of its physical and chemical properties, carrageenan is used in the food industry as a thickening agent, gallant, and stabilizer (Santos et al., 2008). Carrageenan was approved for human consumption by the Brazilian Health Surveillance Agency (ANVISA, 2010) under the resolution number 45 on November 3, 2010. Previous studies have shown that carrageenan can inhibit angiogenesis and metastasis (Parish et al., 1999), act as an immune regulator (Matsubara et al., 2001), and stimulate the activity of oxidizing enzymes (Haijin et al., 2003). 
This study aimed to evaluate the antimutagenic activity and mode of action of carrageenan fiber in cultured meristematic cells of Allium cepa, which is currently considered an important method for screening natural antimutagenic compounds (Fedel-Miyasato et al., 2014; Mauro et al., 2014).

\section{MATERIAL AND METHODS}

\section{DNA damage-inducing agent}

The compound methyl methanesulfonate (MMS) was used at a concentration of 10 $\mu \mathrm{g} / \mathrm{mL}$ to induce DNA damage (Mauro et al., 2014). CSM-2-type carrageenan (Genuvisco ${ }^{\circledR}$, CP Kelco, Chicago, IL, USA) was tested at concentrations of 5, 10, and $20 \mu \mathrm{g} / \mathrm{mL}$. These concentrations were determined in pilot experiments. Both substances were diluted in distilled water to a final volume of $3 \mathrm{~mL}$ for culturing meristematic cells of Allium cepa.

\section{Experimental design}

Commercially available seeds of Allium cepa $\left(\right.$ Topseed $^{\circledR}$; Batch 026111) were used for this experiment. For germination, the seeds were placed on Petri dishes at room temperature, covered with filter paper, and soaked with $3 \mathrm{~mL}$ distilled water. The seeds were germinated for 48-72 h. After the appearance of rootlets, the seeds were cultured for $96 \mathrm{~h}$ under the following treatments and protocols to evaluate mutagenicity and antimutagenicity.

\section{Mutagenicity protocols}

I) Negative control: After the appearance of rootlets, seeds were cultured in distilled water for $96 \mathrm{~h}$.

II) Positive control (MMS): After the appearance of rootlets, seeds were cultured in distilled water for $48 \mathrm{~h}$, transferred to dishes containing $3 \mathrm{~mL}$ aqueous $10 \mu \mathrm{g} / \mathrm{mL}$ MMS solution, and incubated for an additional $48 \mathrm{~h}$.

III) Carrageenan: After the appearance of rootlets, seeds were cultured in distilled water for $48 \mathrm{~h}$, transferred to dishes containing $3 \mathrm{~mL}$ aqueous carrageenan solutions at 5, 10, and $20 \mu \mathrm{g} / \mathrm{mL}$, and incubated for an additional $48 \mathrm{~h}$.

\section{Antimutagenicity protocols}

IV) Pre-treatment: After the appearance of rootlets, seeds were cultured in carrageenan solution $(3 \mathrm{~mL})$ for $48 \mathrm{~h}$, washed twice in distilled water, transferred to dishes containing 3 $\mathrm{mL}$ aqueous $10 \mu \mathrm{g} / \mathrm{mL}$ MMS solution, and incubated for $48 \mathrm{~h}$.

V) Single simultaneous: After the appearance of rootlets, seeds were cultured in distilled water for $48 \mathrm{~h}$, transferred to dishes containing $3 \mathrm{~mL}$ distilled water, and then incubated in dishes containing $3 \mathrm{~mL}$ aqueous solution containing MMS $(10 \mu \mathrm{g} / \mathrm{mL})$ and carrageenan for $48 \mathrm{~h}$.

VI) Simultaneous with pre-incubation: After the appearance of rootlets, seeds were cultured in distilled water for $48 \mathrm{~h}$, transferred to dishes containing $3 \mathrm{~mL}$ distilled water, and then incubated in dishes containing $3 \mathrm{~mL}$ aqueous solution (previously incubated in an oven for $1 \mathrm{~h}$ at $\left.37^{\circ} \mathrm{C}\right)$ containing MMS $(10 \mu \mathrm{g} / \mathrm{mL})$ and carrageenan for $48 \mathrm{~h}$. 
VII) Post-treatment: After the appearance of rootlets, seeds were cultured in $3 \mathrm{~mL}$ aqueous $10 \mu \mathrm{g} / \mathrm{mL}$ MMS solution for $48 \mathrm{~h}$, washed twice in distilled water, transferred to dishes containing $3 \mathrm{~mL}$ aqueous carrageenan solution, and incubated for an additional $48 \mathrm{~h}$.

VIII) Continuous treatment: After the appearance of rootlets, seeds were cultured in carrageenan solution $(3 \mathrm{~mL}$ ) for $48 \mathrm{~h}$, at which point $10 \mu \mathrm{g} / \mathrm{mL}$ MMS was added. For the final $48 \mathrm{~h}$, the seeds were cultured in the presence of carrageenan and MMS.

All antimutagenicity protocols were repeated for the 3 tested concentrations of carrageenan $(5,10$, and $20 \mu \mathrm{g} / \mathrm{mL})$. All mutagenicity and antimutagenicity protocols were performed in duplicate.

\section{Preparation of slides}

Following the protocol of Mauro et al. (2014), with some modifications, the roots were collected at noon and placed in a fixative solution (3:1 acetic acid:ethanol) for at least $6 \mathrm{~h}$. The roots were then subjected to acid hydrolysis to expose the genetic material $(1 \mathrm{~N} \mathrm{HCl}$ for 6 min at $60^{\circ} \mathrm{C}$ ). Immediately afterward, the DNA was stained with Schiff's reagent in the dark. The root tips were sectioned using a blade to extract the meristem. A drop of $2 \%$ acetic carmine was added to stain the cytoplasm, and the meristems were gently crushed. To prepare permanent slides, the coverslip was removed by dipping the entire slide in liquid nitrogen. A new coverslip was then mounted on the biological material using a synthetic resin (Permount ${ }^{\circledR}$ ).

\section{Microscopic analysis, mitotic index (MI), percent reduction of mitotic index (\%RMI), percent reduction of damage $(\% \mathrm{RD})$, and statistical analysis}

Ten thousand cells were analyzed per treatment using a light field microscope at 40X magnification. The MI was obtained by dividing the number of dividing cells (prophase, metaphase, anaphase, and telophase) by the total number of cells analyzed.

$$
\mathrm{MI}=\quad \frac{\text { Dividing cells }}{\text { Total number of cells analyzed }}
$$

The \%RMI was calculated as suggested by Fiskesjö (1993):

$$
\text { MI control }- \text { MI protocols }=(\text { result } \times 100) / \text { MI control }
$$

The $\% \mathrm{RD}$ was obtained using the following equation suggested by Waters et al. (1990):

$$
\% \mathrm{RD}=\left[\frac{\text { Mean of the positive control-Mean of the associated group }}{\text { Mean of the positive control- Mean of the negative control }}\right] \times 100
$$

Statistical analyses were performed with the chi-squared test, and the level of significance was set at $\mathrm{P}<0.0003$. 


\section{RESULTS}

Table 1 shows the data from the chromosomal aberration assay in Allium cepa. Statistical analyses revealed that carrageenan is not mutagenic. In contrast, the antimutagenic tests revealed that carrageenan had chemopreventive activity at all concentrations that were tested.

The pre-treatment protocol yielded \%RDs of $77.34,66.76$, and $64.35 \%$ for carrageenan concentrations of 5,10 , and $20 \mu \mathrm{g} / \mathrm{mL}$, respectively. The same concentrations yielded $\%$ RDs of $84.59,79.56$, and $89.73 \%$ in the single simultaneous treatment protocol. The simultaneous with pre-incubation protocol yielded \%RDs of $86.40,90.63$, and $88.22 \%$. The posttreatment and continuous treatment yielded \%RDs of $81.57,84.59$, and $86.81 \%$ and 96.68 , 84.89 , and $62.54 \%$ for carrageenan concentrations of 5,10 , and $20 \mu \mathrm{g} / \mathrm{mL}$, respectively.

The MI analysis showed that $10 \mu \mathrm{g} / \mathrm{mL}$ carrageenan significantly reduced the number of dividing cells, with a $\%$ RMI of $6.28 \%$. The concentrations of 5 and $20 \mu \mathrm{g} / \mathrm{mL}$, in contrast, significantly increased the MI relative to the negative control.

An analysis of the antimutagenic protocols revealed that a carrageenan concentration of $5 \mu \mathrm{g} / \mathrm{mL}$ reduced the MI by $17.33 \%$ in the pre-treatment protocol. The 10 and $20 \mu \mathrm{g} / \mathrm{mL}$ concentrations reduced the MI by 17.95 and $0.09 \%$, respectively, in the simultaneous treatment with the pre-incubation protocol. The $\%$ RMI was $32.63 \%$ with $5 \mu \mathrm{g} / \mathrm{mL}$ carrageenan in the continuous treatment protocol. In the post-treatment protocol, the concentrations of 10 and $20 \mu \mathrm{g} / \mathrm{mL}$ carrageenan significantly increased the MI by 2.12 and $7.07 \%$, respectively.

The following chromosomal aberrations were observed: micronuclei, shoots, anaphase and telophase bridges, delays, breaks, losses, and binucleation. The most common change was micronuclei, whereas binucleated cells were observed the least frequently.

Table 1. Distribution of chromosomal aberrations, mitotic index (MI), percent reduction of mitotic index $(\% \mathrm{RMI})$, and percent reduction of damage (\%RD) in Allium cepa treatments with carrageenan fiber.

\begin{tabular}{|c|c|c|c|c|c|c|c|c|c|c|c|}
\hline \multirow[t]{2}{*}{ Treatment } & \multirow[t]{2}{*}{$\%$ RMI } & \multirow[t]{2}{*}{ MI } & \multicolumn{7}{|c|}{ Chromosomal Aberrations } & \multirow[t]{2}{*}{ Total } & \multirow[t]{2}{*}{$\% \mathrm{RD}$} \\
\hline & & & $\mathrm{MN}$ & BRI & $\mathrm{BRE}$ & LO & SPR & $\mathrm{DE}$ & $\overline{\text { MUL }}$ & & \\
\hline \multicolumn{12}{|l|}{ Mutagenicity } \\
\hline Negative control & - & 0.1131 & 18 & 17 & - & 1 & 15 & 3 & 1 & 55 & - \\
\hline MMS & 6.81 & 0.1054 & 225 & 31 & - & 9 & 108 & 13 & - & $386^{a *}$ & - \\
\hline Carrageenan $(5 \mu \mathrm{g} / \mathrm{mL})$ & -11.23 & 0.1258 & 43 & 14 & 1 & 2 & 7 & 3 & - & $70^{\mathrm{a}}$ & - \\
\hline Carrageenan $(10 \mu \mathrm{g} / \mathrm{mL})$ & 6.28 & 0.1060 & 27 & 18 & - & 6 & 20 & - & - & $71^{\mathrm{a}}$ & - \\
\hline Carrageenan $(20 \mu \mathrm{g} / \mathrm{mL})$ & -21.22 & 0.1371 & 24 & 25 & 4 & & 13 & 2 & - & $68^{\mathrm{a}}$ & - \\
\hline \multicolumn{12}{|l|}{ Antimutagenicity } \\
\hline Pre-treatment $(5 \mu \mathrm{g} / \mathrm{mL})$ & 3.54 & 0.1091 & 113 & 5 & - & 1 & 9 & 2 & - & $130^{\mathrm{b} *}$ & 77.34 \\
\hline Pre-treatment $(10 \mu \mathrm{g} / \mathrm{mL})$ & 17.33 & 0.0935 & 124 & 16 & - & - & 20 & 5 & - & $165^{\mathrm{b} *}$ & 66.76 \\
\hline Pre-treatment $(20 \mu \mathrm{g} / \mathrm{mL})$ & 12.64 & 0.0988 & 129 & 10 & & 2 & 26 & 3 & - & $170^{\mathrm{b} *}$ & 64.35 \\
\hline Single simultaneous $(5 \mu \mathrm{g} / \mathrm{mL})$ & 11.94 & 0.0996 & 65 & 16 & 1 & - & 22 & 2 & - & $106^{\mathrm{b} *}$ & 84.59 \\
\hline Single simultaneous $(10 \mu \mathrm{g} / \mathrm{mL})$ & 11.23 & 0.1004 & 96 & 11 & - & 3 & 7 & 4 & 1 & $122^{\mathrm{b} *}$ & 79.76 \\
\hline Single simultaneous $(20 \mu \mathrm{g} / \mathrm{mL})$ & 10.08 & 0.1017 & 42 & 25 & 3 & - & 16 & 2 & 1 & $89^{\mathrm{b} *}$ & 89.73 \\
\hline Simultaneous with pre-incubation $(5 \mu \mathrm{g} / \mathrm{mL})$ & 12.38 & 0.0991 & 54 & 20 & - & 2 & 20 & 4 & - & $100^{\mathrm{b} *}$ & 86.40 \\
\hline Simultaneous with pre-incubation $(10 \mu \mathrm{g} / \mathrm{mL})$ & 17.95 & 0.0928 & 59 & 15 & 3 & - & 6 & 3 & - & $86^{\mathrm{b} *}$ & 90.63 \\
\hline Simultaneous with pre-incubation $(20 \mu \mathrm{g} / \mathrm{mL})$ & 0.09 & 0.1132 & 37 & 24 & - & - & 28 & 5 & - & $94^{\mathrm{b} *}$ & 88.22 \\
\hline Post-treatment $(5 \mu \mathrm{g} / \mathrm{mL})$ & 2.39 & 0.1104 & 66 & 17 & - & 4 & 25 & 4 & - & $116^{\mathrm{b} *}$ & 81.57 \\
\hline Post-treatment $(10 \mu \mathrm{g} / \mathrm{mL})$ & -2.12 & 0.1155 & 58 & 17 & 2 & 4 & 20 & 5 & - & $106^{\mathrm{b} *}$ & 84.59 \\
\hline Post-treatment $(20 \mu \mathrm{g} / \mathrm{mL})$ & -7.07 & 0.1211 & 48 & 21 & - & 4 & 22 & 4 & - & $99^{\mathrm{b} *}$ & 85.71 \\
\hline Continuous $(5 \mu \mathrm{g} / \mathrm{mL})$ & 32.63 & 0.0762 & 50 & 4 & 2 & - & 10 & - & - & $66^{\mathrm{b} *}$ & 96.66 \\
\hline Continuous $(10 \mu \mathrm{g} / \mathrm{mL})$ & 12.82 & 0.0986 & 82 & 13 & 1 & 2 & 7 & - & - & $105^{\mathrm{b} *}$ & 84.89 \\
\hline Continuous $(20 \mu \mathrm{g} / \mathrm{mL})$ & 1.41 & 0.1115 & 130 & 13 & 3 & 1 & 31 & 1 & - & $179^{\mathrm{b} *}$ & 62.54 \\
\hline
\end{tabular}

MMS = methyl methanesulfonate; $\mathrm{MN}=$ micronucleus; $\mathrm{BRI}=$ bridge; $\mathrm{BRE}=$ break; $\mathrm{LO}=$ loss; $\mathrm{SPR}=$ sprout; $\mathrm{DE}$ $=$ delay; MUL = binucleated cell. ${ }^{\text {a } V a l u e s ~ c o m p a r e d ~ t o ~ t h e ~ c o n t r o l ~ g r o u p . ~}{ }^{b}$ Values compared to the MMS group. *Statistically significant difference $(\mathrm{P}<0.0003$, chi-squared test). 


\section{DISCUSSION}

Biological assays such as the Allium cepa test are efficient for evaluating and describing the mode of antimutagenic action of natural products (Fedel-Miyasato et al., 2014; Mauro et al., 2014). The Allium cepa assay has been increasingly used to screen antimutagenic and suspected anticancer substances, as these events are related. This claim is supported by studies offering sufficient information to indicate that cancer can be induced by mutational events (Vogel, 1982).

The literature shows that diet can act as an important factor in preventing the emergence of mutations by acting directly on xenobiotics that can alter genetic material (el Hamss and Idaomar, 2002) and modulate DNA repair enzymes. Demutagenic and bio-antimutagenic actions can be inferred from the aforementioned events, respectively, and have been linked to fibers such as $\beta$-glucan (Oliveira et al., 2006, 2007, 2013), inulin (Mauro et al., 2013, 2014), wheat (Pesarini et al., 2013), and insoluble fibers from carrot, broccoli, and spinach (Lee et al., 1995).

Carrageenan is an important food additive that is approved for human consumption by regulatory agencies (ANVISA, 2010). It has been reported to inhibit the proliferation of HeLa cells despite having low cytotoxicity (Chen et al., 2011). Additionally, carrageenan can block angiogenesis and metastasis and is an immune regulator that is capable of stimulating oxidizing enzymes (Parish et al., 1999; Matsubara et al., 2001; Haijin et al., 2003; Chen et al., 2011). Other studies indicate that compounds similar to the one tested, such as kappa-type carrageenan, do not cause histopathological changes in the gastrointestinal tracts of mice, even when supplemented for up to 90 days (Weiner et al., 2007). A lack of adverse effects was also reported in humans who consumed a diet rich in carrageenan (European Commission, 2003). Given these findings, it is necessary to confirm the antimutagenic activity of this compound and describe its mode of action so that it can be used in a directed manner in the formulation of functional foods.

The results of this showed that carrageenan is not mutagenic. This finding agrees with that from the study by Watanabe et al. (1978), who also found no evidence of mutagenic activity from carrageenan supplementation and no correlation with the emergence of colon cancer when this fiber was administered alone. Such results highlight the need to understand the antimutagenic mode of action of this fiber and to test the possibility of its use as a chemopreventive supplement, because it is a low-cost product that can be easily integrated in the diet.

Kada (1981) identified 2 modes by which a substance can act to prevent and/or repair mutagenic damage: demutagenicity and bio-antimutagenicity. Compounds with a demutagenic mode of action act mainly by adsorbing agents that can cause DNA damage; this action is predominantly extracellular. Compounds with bio-antimutagenic activity act inside cells and can modulate DNA repair enzymes (De Flora, 1998). Thus, the following 4 experimental protocols were proposed to clarify the antimutagenic mode of action of carrageenan (Mauro et al., 2014): pre-treatment, single simultaneous, simultaneous with pre-incubation, and posttreatment. Additionally, we developed a continuous treatment that combines the pre-treatment and simultaneous treatment protocols.

In this study, the \%RDs for the various concentrations and protocols tested were similar, ranging from $62.54 \%$ at the highest dose in the continuous protocol to $96.66 \%$ at the lowest dose in the same treatment protocol. A dose-response correlation was only observed for the post-treatment protocol, where the \%RDs were $81.57,84.59$, and $85.71 \%$ for carrageenan doses of 5, 10, and $20 \mu \mathrm{g} / \mathrm{mL}$, respectively. Despite this dose-response correlation, a general 
analysis of the results does not support the use of higher doses to more effectively achieve the desired antimutagenic effect.

In terms of antimutagenic effects, the simultaneous treatment with pre-incubation indicates demutagenic activity because the compounds were pre-incubated for $1 \mathrm{~h}$, allowing the mutagenic compound and suspected chemopreventive agent to interact. In this scenario, the former is inactivated by the latter, leading to lower levels of DNA damage. Here, it could be assumed that the action occurs mainly in the extracellular environment. However, inactivation could also occur to a lesser degree if both compounds were intracellular.

Potential bio-antimutagenic activity can be evaluated by post-treatment protocols, where the cultured cells are first exposed to the mutagen and are subsequently ( $48 \mathrm{~h}$ later in this study) exposed to the suspected chemopreventive agent. In this scenario, any protective effect can be attributed to the capacity of the chemopreventive compound to modulate the activity of DNA repair enzymes because the mutagenic damage would have already occurred during the earlier exposure to the mutagen. Here, the bio-antimutagenic activity occurs inside the cell and depends on DNA repair enzymes. These claims were tested in studies by Filipic et al. (2002); Oliveira et al. (2006, 2007); Mauro et al. (2013); and Pesarini et al. (2013). In this study, the \%RDs for the simultaneous with pre-incubation protocol ranged from 86.40 to $90.63 \%$; in the post-treatment protocol, they ranged from 81.57 to $85.71 \%$. Thus, we conclude that carrageenan is capable of both modes of action and that neither mode seems to predominate because the values were similar.

The pre-treatment and single simultaneous treatment protocols do not distinguish between modes of action, but they are important for evaluating chemopreventive activity. The pre-treatment protocol involves exposing cultured cells first to the chemopreventive agent and then to the mutagenic compound. In this case, it is believed that the chemopreventive compound first enters the cell, persists in the intracellular space, and possibly modulates DNA repair enzymes. When the mutagenic agent reaches the intracellular space, it can be directly inactivated by the chemopreventive agent. If the mutagen causes damage to the genetic material, it can be repaired immediately by previously modulated enzymes. Thus, both demutagenic and bio-antimutagenic actions can be detected in the same protocol; however, it is assumed that the latter occurs to a greater degree. In the single simultaneous protocol, where both compounds enter the cells simultaneously, it is assumed that they can inactivate each other or perform different actions. In other words, while the mutagen causes DNA damage, the chemopreventive agent modulates the repair enzymes. In the end, both actions culminate in the prevention/correction of mutagenic damage. Again, both modes of action can be observed in this protocol (Kuroda et al., 2001; Oliveira et al., 2007; Malini et al., 2010; Mauro et al., 2013; Pesarini et al., 2013). In this study, the \%RDs for pre-treatment ranged from 64.35 to $77.34 \%$; for the single simultaneous treatment, they ranged from 79.76 to $89.73 \%$. These findings suggest good efficiency for both proposed modes of action.

The continuous treatment tested whether increasing the exposure time to the chemopreventive agent resulted in greater prevention of mutagenic damage. The observed \%RDs, which ranged from 62.54 to $96.66 \%$, did not suggest the need to extend treatment because similar percentages were obtained in other protocols.

The literature states that a greater than $50 \%$ reduction in mitotic index is required for a substance to be considered toxic and that reductions up to $36 \%$, relative to a control group, can be considered normal (Fiskesjö, 1993). Reductions above 36\% indicate strong mutagenic activity because DNA damage can cause delays in the cell cycle. 
The antimutagenicity protocols showed an increase in the cell division rate for the post-treatment protocol with carrageenan concentrations of 10 and $20 \mu \mathrm{g} / \mathrm{mL}$. These values are still lower than those reported for treatment with carrageenan alone. The remaining treatments yielded values below $36 \%$, indicating a lack of cell cycle delays related to severe DNA damage. Only the $5 \mu \mathrm{g} / \mathrm{mL}$ dose yielded a \%RMI near 36\% (32.63\%). Because this was an isolated effect, it is not associated with toxicity.

Oliveira et al., 2006, 2007 reported the antimutagenic mode of action of $\beta$-glucan in mammalian cell culture. According to these authors, regardless of the polysaccharide source (barley or Saccharomyces cerevisiae), $\beta$-glucan can act by both demutagenesis and bio-antimutagenesis; however, the latter is less effective. The protocols used by those authors were modified by Mauro et al. (2014) to evaluate the mode of action of another fiber, inulin, which was previously systematically described as an anticancer agent. In that study, the authors demonstrated that inulin was also an important antimutagenic agent that can act by both demutagenesis and bio-antimutagenesis. That study also supports the use of the Allium cepa assay to describe the mode of action of natural products. Thus, using this assay to screen for the antimutagenic action of carrageenan opens new lines of research on this fiber as a potential antimutagenic and anticancer agent in animal models and its possible inclusion in chemopreventive diets. The Joint FAO/WHO Expert Committee on Food Additives (JECFA, 2002) indicated that consuming carrageenan as a nutritional supplement is safe and that there are no restrictions on its use. However, a study by Weiner et al. (2007) reported a recommended intake in Europe of up to $75 \mathrm{mg} / \mathrm{kg}$. That study stressed the lack of toxicity in in vivo mediumterm trials. Additionally, a study by Yuan and Song (2005) reported the anti-angiogenic and antioxidant activities of carrageenan.

If carrageenan is viewed as an antioxidant agent, then the following 3 modes of action can be assumed: I) ability to protect cells or organisms against the formation of aggressive substances derived from reactive oxygen species; II) ability to intercept free radicals, which immediately initiate DNA oxidation upon formation, causing damage that can lead to mutations (Santos and Cruz, 2001) (a demutagenic activity of carrageenan would be assumed in this case); and III) participation in the cellular response to situations where prevention and interception are ineffective and byproducts of free radical activity are continuously formed at low levels and accumulate in the body. Here, there is a need for detoxifying enzymes to transport the accumulated byproducts for excretion and for antioxidants to modulate the DNA repair system of cells under attack.

Under these possible forms of action, there are reports that antioxidants, even when present at low concentrations, can slow or inhibit oxidation rates (Sies, 1993). The most commonly used classification for such substances divides them into 2 systems: enzymatic, consisting of enzymes produced in the body, and non-enzymatic, consisting of vitamins, flavonoids, lycopene, and bilirubin (Sies, 1993). Carrageenan may fit in the latter group.

Sulfated polysaccharides, such as carrageenan, are organic compounds that derive their antioxidant activity from their ability to activate detoxifying enzymes present in the liver (Moraes and Colla, 2006). The tripeptide glutathione, especially in the reduced form, is present in most cells and is the most abundant thiol (-SH) in the intracellular space. Glutathione's reduction ability is associated with the - $\mathrm{SH}$ group present on cysteine. Glutathione is known to be a substrate for glutathione transferases and glutathione peroxidases, which are enzymes that catalyze detoxification reactions for xenobiotic compounds and antioxidant reactions for reactive oxygen species and free radicals (Bray and Taylor, 1993). The concentration of glu- 
tathione in tissues can be regulated by the diet and nutritional status. Thus, consuming carrageenan, or in the case of this study, increasing the availability of this polysaccharide, raises the levels of -SH groups available for detoxifying enzymes (Vannucchi et al., 1997). Such an effect would be favorable for the prevention of mutagenic damage.

Given the prior reports and the study by Haijin et al. (2003), who claimed that sulfated polysaccharides, such as carrageenan, have antitumor/anti-angiogenic activities related to their ability to interfere with the functions of angiogenic growth factors, combined with the pioneering description of the antimutagenic mode of action of this polysaccharide offered by this study, we suggest that carrageenan be considered an important fiber for use as a base in functional foods and/or diets with potential antioxidant and antimutagenic activities. Future in vivo studies will need to address the efficacy of this strategy.

\section{ACKNOWLEDGMENTS}

The authors thank the company $\mathrm{Cp} \mathrm{Kelco}{ }^{\circledR}$ for their support and donating the substance used in this study (Carrageenan CSM-2).

\section{REFERENCES}

Antunes LMG and Araújo MCP (2000). Mutagenicity and antimutagenicity of the main food colorings. Rev. Nutr. 13: 81-88.

ANVISA (2010). Agência Nacional de Vigilância Sanitária. Available at [http://portal.anvisa.gov.br/wps/wcm/connect/1 $1707300474597459 \mathrm{fc} 3 \mathrm{df3fbc4c6735/Resolu} \% \mathrm{C} 3 \% \mathrm{~A} 7 \% \mathrm{C} 3 \% \mathrm{~A} 3 \mathrm{o} \% \mathrm{C} 2 \% \mathrm{~B} 1 \mathrm{da} \% \mathrm{C} 2 \% \mathrm{~B} 1$ Diretoria $\% \mathrm{C} 2 \% \mathrm{~B} 1$ Colegia $\mathrm{da} \% \mathrm{EF} \% \mathrm{BF} \% \mathrm{BD} \% \mathrm{C} 2 \% \mathrm{~B} 1 \mathrm{RDC} \% \mathrm{C} 2 \% \mathrm{~B} 1 \mathrm{n} \% \mathrm{EF} \% \mathrm{BF} \% \mathrm{BD} \% \mathrm{C} 2 \% \mathrm{~B} 145 \% \mathrm{C} 2 \% \mathrm{~B} 1 \mathrm{de} \% \mathrm{C} 2 \% \mathrm{~B} 103 \% \mathrm{C} 2 \% \mathrm{~B} 1 \mathrm{de} \% \mathrm{C} 2$ \%B1 novembro\%C2\%B1de\%C2\%B12010.pdf?MOD=AJPERES]. Accessed February 14, 2014.

Bray TM and Taylor CG (1993). Tissue glutathione, nutrition, and oxidative stress. Can. J. Physiol. Pharmacol. 71: 746751.

Chen HM, Gao Y and Yan XJ (2011). Carrageenan oligosaccharides inhibit growth-factor binding and heparanase activity. Yao Хие Хие Bao. 46: 280-284.

De Flora S (1998). Mechanisms of inhibitors of mutagenesis and carcinogenesis. Mutat. Res. 402: 151-158.

De Flora S and Ferguson LR (2005). Overview of mechanisms of cancer chemopreventive agents. Mutat. Res. 591: 8-15.

el Hamss R and Idaomar M (2002). Antimutagens and anticarcinogenic agents, identification and mechanisms of action of food xenobiotics. Therapie 57: 512-517.

European Commission (2003). Health \& Consumer Protection Directorate - General, Opinion of the Scientific Committee on Food on Carrageenan, SCF/CS/ADD/EMU/199. Available at [http://ec.europa.eu/food/fs/sc/scf/out164_en.pdf]. Accessed February 14, 2014.

Fedel-Miyasato LES, Formagio AS, Auharek SA, Kassuya CAL, et al. (2014). Antigenotoxic and antimutagenic effects of Schinus terebinthifolius Raddi in Allium cepa and Swiss mice: a comparative study. Genet. Mol. Res. 13: 3411-3425.

Filipic M, Umek A and Mlinaric A (2002). Screening of Basidiomycete mushroom extracts for antigenotoxic and bioantimutagenic activity. Pharmazie 57: 416-420.

Fiskesjö G (1993). The Allium test in wastewater monitoring. Environ. Toxicol. Water Qual. 8: 291-298.

Haijin M, Xiaolu J and Huashi G (2003). A k-carrageenan derived oligosaccharide prepared by enzymatic degradation containing anti-tumor activity. J. Appl. Phycol. 15: 297-303.

JECFA (2002). Safety Evaluation of Certain Food Additives and Contaminants. Prepared by the Fifty-Seventh Meeting of the Joint FAO/WHO Expert Committee on Food Additives Series 48: 91-101. Available at [http://www.inchem.org/ documents/jecfa/jecmono/v48je08.htm]. Accessed February 14, 2014.

Kada T (1981). Environmental desmutagens and antidesmutagens. Indian J. Biochem. Biophys. 18: 5-6.

Khotimchenko YS (2010). The antitumor properties of nonstarch polysaccharides: carrageenans, alginates, and pectins. Russ. J. Mar. Biol. 36: 401-412.

Kuroda Y, Shima N, Yazawa K and Kaji K (2001). Desmutagenic and bio-antimutagenic activity of docosahexaenoic acid and eicosapentaenoic acid in cultured Chinese hamster V79 cells. Mutat. Res. 497: 123-130.

Lee SM, Rhee SH, Park KY, Rh-ew TH, et al. (1995). Antimutagenic effect of insoluble dietary fibers from some green 
yellow vegetables and soybean by binding the carcinogens. J. Life. Sci. 5: 26-32.

Malini M, Marin-Morales MA, Mantovani MS, Jamal CM, et al. (2010). Determination of the antimutagenicity of an aqueous extract of Rhizophora mangle L. (Rhizophoraceae), using in vivo and in vitro test systems. Genet. Mol. Biol. 33: 176-181.

Matsubara K, Matsuura Y, Bacic A, Liao M, et al. (2001). Anticoagulant properties of a sulfated galactan preparation from a marine green alga, Codium cylindricum. Int. J. Biol. Macromol. 28: 395-399.

Mauro MO, Monreal MT, Silva MT, Pesarini JR, et al. (2013). Evaluation of the antimutagenic and anticarcinogenic effects of inulin in vivo. Genet. Mol. Res. 12: 2281-2293.

Mauro MO, Pesarini JR, Marin-Morales MA, Monreal MT, et al. (2014). Evaluation of the antimutagenic activity and mode of action of the fructooligosaccharide inulin in the meristematic cells of Allium cepa culture. Genet. Mol. Res. 13: 4808-4819.

Mišurcová L, Skrovankova S, Samek D, Ambrozova J, et al. (2012). Health benefits of algal polysaccharides in human nutrition. Adv. Food Nutr. Res. 66: 75-145.

Moraes FP and Colla LM (2006). Functional foods and nutraceuticals: definition, legislation and health benefits. Rev. Elet. Farm 3: 109-122.

Obe G, Pfeiffer P, Savage JR, Johannes C, et al. (2002). Chromosomal aberrations: formation, identification and distribution. Mutat. Res. 504: 17-36.

Oliveira RJ, Ribeiro LR, da Silva AF, Matuo R, et al. (2006). Evaluation of antimutagenic activity and mechanisms of action of beta-glucan from barley, in CHO-k1 and HTC cell lines using the micronucleus test. Toxicol. In Vitro 20: 1225-1233.

Oliveira RJ, Matuo R, da Silva AF, Matiazi HJ, et al. (2007). Protective effect of beta-glucan extracted from Saccharomyces cerevisiae, against DNA damage and cytotoxicity in wild-type (k1) and repair-deficient (xrs5) CHO cells. Toxicol. In Vitro 21: 41-52.

Oliveira RJ, Salles MJ, da Silva AF, Kanno TY, et al. (2013). In vivo evaluation of the antimutagenic and antigenotoxic effects of beta-glucan extracted from Saccharomyces cerevisiae in acute treatment with multiple doses. Genet. Mol. Biol. 36: 413-424.

Parish CR, Freeman C, Brown KJ, Francis DJ, et al. (1999). Identification of sulfated oligosaccharide-based inhibitors of tumor growth and metastasis using novel in vitro assays for angiogenesis and heparanase activity. Cancer Res. 59: 3433-3441.

Pesarini JR, Zaninetti PT, Mauro MO, Carreira CM, et al. (2013). Antimutagenic and anticarcinogenic effects of wheat bran in vivo. Genet. Mol. Res. 12: 1646-1659.

Saksena R, Deepak D, Khare A, Sahai R, et al. (1999). A novel pentasaccharide from immunostimulant oligosaccharide fraction of buffalo milk. Biochim. Biophys. Acta 1428: 433-445.

Santos FP, Bruniera LB and Garcia CER (2008). Carragena, uma visão ambiental. Terra Cultura 47: 58-65.

Santos HS and Cruz WMS (2001). The antioxidant vitamin nutritional therapy and the chemotherapy treatment in oncology. Rev. Bras. Canc. 47: 303-308.

Sies H (1993). Strategies of antioxidant defense. Eur. J. Biochem. 215: 213-219.

Vannucchi H, Jordao Junior AA, Iglesias AC, Morandi MV, et al. (1997). Effect of different dietary levels of vitamin E on lipid peroxidation in rats. Arch. Latinoam. Nutr. 47: 34-37.

Vogel EW (1982). Assessment of Chemically Induced Genotoxic Events, Prospectives and Limitations. 2nd edn. Universitaire Pers Leiden, Leiden.

Watanabe K, Reddy BS, Wong CQ and Weisburger JH (1978). Effect of dietary undegraded carrageenan on colon carcinogenesis in F344 rats treated with azoxymethane or methylnitrosourea. Cancer Res. 38: 4427-4430.

Waters MD, Brady AL, Stack HF and Brockman HE (1990). Antimutagenicity profiles for some model compounds. Mutat. Res. 238: 57-85.

Weiner ML, Nuber D, Blakemore WR, Harriman JF, et al. (2007). A 90-day dietary study on kappa carrageenan with emphasis on the gastrointestinal tract. Food Chem. Toxicol. 45: 98-106.

Yuan H and Song J (2005). Preparation, structural characterization and in vitro antitumor activity of kappa-carrageenan oligosaccharide fraction from Kappaphycus striatum. J. Appl. Phycol. 17: 7-13.

Zong A, Cao H and Wang F (2012). Anticancer polysaccharides from natural resources: a review of recent research. Carbohydr. Polym. 90: 1395-1410. 